\title{
Deteksi Dini dan Edukasi Pentingnya Penatalaksanaan Depresi dan Faktor- Faktor Resikonya pada Pasien Stroke Iskemik di RSUD Provinsi Nusa Tenggara Barat
}

\author{
Herpan Syafii Harahap $^{1 *}$, Yanna Indrayana ${ }^{2}$, Hendra Susana Putra ${ }^{3}$, Indah Retnowati ${ }^{3}$ \\ ${ }^{\text {I} D e p a r t e m e n ~ N e u r o l o g i, ~ F a k u l t a s ~ K e d o k t e r a n ~ U n i v e r s i t a s ~ M a t a r a m, ~ M a t a r a m, ~ I n d o n e s i a ; ~}$ \\ ${ }^{2}$ Departemen Kardiologi, Fakultas Kedokteran Universitas Mataram, Mataram, Indonesia; \\ ${ }^{3}$ Laboratorium Terpadu, Fakultas Kedoketran Universitas Mataram, Mataram, Indonesia.
}

\section{DOI: https://doi.org/10.29303/jpmsi.v3i1.109}

Citation: Harahap, H. S., Indrayana, Y., Putra, H. S., Retnowati, I. 2021. Deteksi Dini dan Edukasi Pentignya Penatalaksanaan Depresi dan Faktor-Faktor Resikonya pada Pasien Stroke Iskemik di RSUD Provinsi Nusa Tenggara Barat. Jurnal Pengabdian Masyarakat Sains Indonesia (JPMSI). 3(1):219-225.

\section{Article history}

Received: May $08^{\text {th }} 2021$

Revised: May $26^{\text {th }} 2021$

Accepted: June $25^{\text {th }} 2021$

*Corresponding Author: Herpan

Syafii Harahap, Departemen

Neurologi, Fakultas Kedokteran

Universitas Mataram, Mataram,

Indonesia;

Email: herpanharahap@unram.ac.id
Abstract: Depression is one of the important complications of ischemic stroke. The global prevalence of depression in stroke patients is quite high, which is about $55 \%$. The ignorance of depression among stroke patients due to their lack of information regarding the importance of depression and its risk factors managements will lead to a decrease in the quality of life of the patients. Therefore, the event aimed at early detection of post-stroke depression and education regarding the importance of the management of depression and its associated risk factors in ischemic stroke patients is important. A total of 22 ischemic stroke outpatients within the first 3 months from the stroke onset who visit the Neurology Department of West Nusa Tenggara General Hospital during August 2019 to March 2020 participated as subjects in this event. The frequency of depression in these subjects was quite high (45\%). Most of them had a productive age range, male gender, low education attainment, involvement of left hemisphere, and hypertension. All identified demographic and clinical characteristics were not significantly associated with the frequency of post-stroke depression $(\mathrm{p}<0.05)$. All subjects and their accompanying family members showed high enthusiasm for this event. This early detection for depression and education regarding the importance of management of depression and its risk factors are useful for the subjects and their accompanying relatives in increasing their knowledge regarding the follow-up that should be carried out to prevent or treat post-stroke depression.

Keywords: stroke, depression, quality of life, promotion, prevention

Abstrak: Depresi merupakan salah satu komplikasi penting dari stroke iskemik. Prevalensi depresi pada pasien stroke secara global cukup tinggi, yaitu sekitar 55\%. Pengabaian kondisi depresi pada pasien stroke akibat rendahnya pemahaman mereka mengenai pentingnya penanganan depresi dan faktor-faktor risikonya akan menyebabkan terjadinya penurunan kualitas hidup pasiennya. Oleh karena itu, pengabdian masyarakat yang ditujukan untuk deteksi dini depresi pasca stroke dan edukasi terkait pentingnya penatalaksanaan depresi dan faktor-faktor risiko penyertanya pada pasien stroke iskemik penting untuk dilakukan. Sebanyak 22 pasien stroke iskemik dengan waktu awitan stroke 3 bulan pertama yang datang ke Poli 
Saraf Rumah Sakit Umum Daerah Provinsi Nusa Tenggara Barat selama Bulan Agustus 2019 sampai dengan Maret 2020 turut berpartisipasi sebagai subjek dalam kegiatan ini. Frekuensi depresi pada subjek dengan stroke iskemik yang berpartisiapasi dalam kegiatan pengabdian ini cukup tinggi $(45 \%)$. Sebagian besar subjek memiliki rentang usia produktif, berjenis kelamin laki-laki, memiliki tingkat pendidikan rendah, memiliki lokasi infark pada hemisfer kiri, dan memiliki hipertensi. Seluruh karakteristik demografik dan klinik yang teridentifikasi tidak berhubungan secara signifikan dengan frekuensi kejadian depresi pasca stroke $(\mathrm{p}<0.05)$. Seluruh subjek dan anggota keluarga yang mendampinginya menunjukkan antusiasme yang tinggi dalam kegiatan ini. Kegiatan deteksi dini depresi ini sangat bermanfaat bagi subjek dan edukasi terkait pentingnya penatalaksanaan depresi dan faktor-faktor risikonya ini bermanfaat dalam meningkatkan pengetahuan mereka terkait tindak lanjut yang harus dilakukan untuk mencegah atau mengatasi depresi pasca stroke.

Kata kunci: stroke, depresi, kualitas hidup, promotif, preventif

\section{Pendahuluan}

Depresi merupakan salah satu komplikasi penting dari stroke iskemik. Depresi yang terjadi pada pasien stroke iskemik tersebut memiliki spektrum yang luas, yaitu mulai dari depresi ringan sampai dengan depresi berat. Prevalensi depresi pada pasien stroke secara global cukup tinggi, yaitu sekitar 55\% (Towfighi et al., 2017; ). Dengan semakin tingginya insiden stroke iskemik, maka prevalensi depresi pasca stroke dapat diperkirakan akan terus mengalami peningkatan. Depresi pada pasien stroke tersebut memiliki dampak yang buruk terhadap luaran klinis stroke iskemik dan kualitas hidup pasiennya, baik pada jangka pendek maupun jangka panjang (Ezema et al., 2018; Schottke et al., 2020).

Kerentanan pasien stroke iskemik untuk mengalami depresi secara umum ditentukan oleh karakteristik demografik dan klinik yang dimilikinya. Usia dewasa muda, jenis kelamin perempuan, dan tingkat pendidikan tinggi merupakan karakteristik demografik yang menjadi faktor risiko untuk terjadinya depresi pada pasien stroke iskemik (Shi et al., 2017). Diantara faktorfaktor risiko vaskuler, hipertensi merupakan faktor risiko utama untuk terjadinya depresi pada pasien stroke (Tennen et al., 2011). Lokasi infark di hemisfer kiri, terutama di region lobus frontal dan ganglia basalis kiri, merupakan prediktor untuk terjadinya depresi pada stroke iskemik akut maupun subakut (Shi et al., 2017). Dengan demikian, deteksi dini dan intervensi yang tepat terhadap kejadian depresi dan faktor-faktor risikonya merupakan salah satu strategi penting untuk mencapai luaran klinis yang optimal bagi pasien stroke iskemik.

Pemahaman pasien dan/atau anggota keluarga yang mengasuhnya terkait pentingnya dampak merupakan faktor penting yang turut menentukan keberhasilan pencegahan dan pengobatan depresi pasca stroke iskemik (Towfighi et al., 2017; Shi et al., 2017). Dukungan anggota keluarga yang rendah berkorelasi dengan kejadian dan derajat berat depresi (Harahap et al., 2017). Pengabaian kondisi depresi pada pasien stroke akibat rendahnya pemahaman mereka mengenai pentingnya penanganan depresi dan faktor-faktor risikonya tersebut akan menyebabkan terjadinya penurunan kualitas hidup pasiennya yang selanjutnya berakibat pada ketrgantungan tinggi pasien terhadap anggota keluarganya, kompleksitas pengobatan, dan tingginya beban sosio-ekonomi bagi pasien dan keluarga (Husaini et al., 2013; Paolucci et al., 2019).

Oleh karena itu, pengabdian masyarakat yang ditujukan untuk deteksi dini depresi pasca stroke dan edukasi terkait pentingnya penatalaksanaan depresi dan faktor-faktor risiko penyertanya pada pasien stroke iskemik di Kota Mataram sangat penting untuk dilakukan. Deteksi dini depresi dalam kegiatan pengabdian masyarakat ini ditujukan terhadap pasien stroke iskemik rawat jalan di RSUD Provinsi NTB dengan onset stroke dalam 3 bulan pertama. Mengingat kegiatan ini dilaksanakan pada masa pandemi Covid-19, maka 
Harahap et al, Jurnal Pengabdian Masyarakat Sains Indonesia 2021, 3 (1): 219-225. DOI: https://doi.org/10.29303/jpmsi.v3i1.109

seluruh rangkaian kegiatan yang membutuhkan kontak dengan pasien dalam kegiatan pengabdian kepada masyarakat ini dilaksanakan dengan menerapkan protokol pencegahan penularan infeksi Covid-19.

\section{Metode}

Kegiatan ini dilaksanakan di Poli Saraf Rumah Sakit Umum Daerah (RSUD) Provinsi Nusa Tenggara Barat (NTB) selama Bulan Agustus 2019 - Maret 2020. Subjek yang menjadi sasaran kegiatan pengabdian masyarakat ini adalah pasien stroke iskemik dengan awitan stroke 3 bulan pertama. Subjek yang memenuhi kriteria tersebut menjalani pemeriksaan untuk penapisan depresi dan identifikasi faktor-faktor risiko yang dimilikinya dengan didampingi oleh salah satu anggota keluarganya. Dalam pertemuan tersebut, subjek akan menjalani 3 sesi kegiatan, antara lain penapisan depresi, identifikasi karakteristik demografik dan klinik yang menjadi faktor risiko terjadinya depresi pasca stroke, dan edukasi terhadap subjek dan/atau keluarganya terkait pentingnya upaya penanganan depresi pasca stroke dan faktor-faktor risiko yang menyertainya.

Penapisan depresi dalam kegiatan ini dilakukan dengan menggunakan instrumen Beck's Depression Inventory second edition (BDI-II), suatu instrumen yang sudah tervalidasi untuk digunakan dalam penapisan keberadaan depresi pada berbagai kondisi medis, termasuk pada penyakit stroke. Instrumen ini memiliki rentang skor $0-63$. Subjek dengan skor $0-10$ dikategorikan normal dan mereka yang memiliki skor > 10 dikategorikan memiliki depresi (StHilaire et al., 2016).

Pada tahap identifikasi karakteristik demografik dan klinik yang menjadi faktor risiko terjadinya depresi pasca stroke yang diambil dari setiap subjek yang berpartisipasi dalam kegiatan pengabdian ini antara lain usia, jenis kelamin, lama pendidikan formal, hemisfer otak yang terkena, status merokok, hipertensi, diabetes melitus, dislipidemia, kegemukan (overweight), dan atrial fibrilasi. Lama pendidikan formal subjek dikategorikan menjadi rendah $(\leq 12$ tahun) dan tinggi (>12 tahun). Data kegemukan (overweight) didapatkan berdasarkan pada indeks massa tubuh (IMT) subjek, yang merupakan hasil bagi berat badan dalam satuan kilogram dengan kuadrat tinggi
e-ISSN : 2715-2537

p-ISSN : 2715-2545

badan dalam satuan meter. Berdasarkan IMT tersebut, subjek dikategorikan mengalami kegemukan (IMT $\geq 25 \mathrm{~kg} / \mathrm{m}^{2}$ ) dan tidak mengalami kegemukan (IMT $<25 \quad \mathrm{~kg} / \mathrm{m}^{2}$ ). Data-data karakteristik demografik dan klinik tersebut diatas diperoleh dari rekam medik setiap subjek dan dikonfirmasi kepada kepada subjek yang bersangkutan dan/atau keluarga yang mendampinginya.

Pada tahap selanjutnya, subjek diberikan informasi mengenai hasil penapisan depresi dan identifikasi faktor-faktor risiko penyertanya. Subjek dengan stroke iskemik yang mengalami depresi diberikan edukasi terkait dampak penurunan kapasitas fungsional yang dapat ditimbulkan oleh kondisi depresi tersebut dan upaya pengobatan yang bisa dilakukan, baik secara farmakologis maupun non-farmakologis. Subjek yang masih belum mengalami depresi juga diberikan edukasi terkait pentingnya penanganan faktor-faktor risiko yang dimilikinya, terutama faktor-faktor risiko vaskuler yang telah berhasil diidentifikasi, sebagai upaya preventif terhadap terjadinya depresi pasca stroke.

Analisis statistik dilakukan untuk menilai signifikansi hubungan antara faktor-faktor risiko untuk terjadinya depresi pasca stroke yang berhasil diidentifikasi dan kejadian depresi. Data-data terkait faktor-faktor risiko untuk terjadinya depresi pasca stroke dan kejadian depresi pasca stroke itu sendiri dari seluruh subjek peserta kegiatan pengabdian kepada masyarakat ini akan disajikan dalam tabel distribusi frekuensi. Hubungan antara faktor-faktor risiko depresi pasca stroke dan kejadian depresi pada subjek-subjek tersebut akan dianalisis secara statistik dengan uji kai-kuadrat. Hasil analisis statistik tersebut signifikan jika didapatkan nilai $\mathrm{p}<0.05$.

\section{Hasil dan Pembahasan}

Selama 8 bulan pelaksanaan kegiatan pengabdian kepada masyarakat ini, sebanyak 22 orang subjek dengan awitan stroke iskemik 3 bulan pertama yang datang ke Poli Saraf RSUD Provinsi NTB turut berpartisipasi. Sebagian besar dari mereka sebelumnya adalah pasien rawat inap di RSUD Provinsi NTB yang dijadwalkan untuk kontrol di poli saraf tersebut. Seluruh subjek berpartisipasi penuh dalam kegiatan ini yang menunjukkan tingginya tingkat kesadaran mereka 
Harahap et al, Jurnal Pengabdian Masyarakat Sains Indonesia 2021, 3 (1): 219-225. DOI: https://doi.org/10.29303/jpmsi.v3i1.109

terhadap pentingnya deteksi dini depresi pasca stroke dan identifikasi faktor-faktor risikonya, serta edukasi terkait pentingnya penatalaksanaannya (Gambar 1).

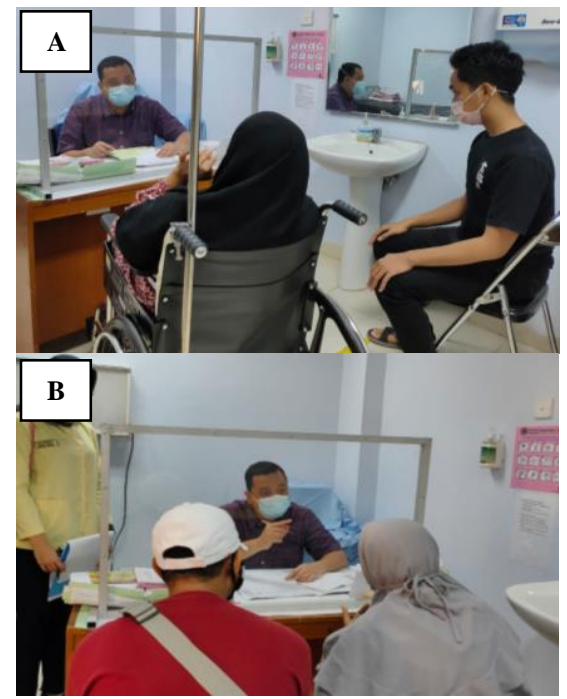

Gambar 1. Dokumentasi kegiatan pengabdian kepada masyarakat di RSUD Provinsi NTB. (A) Pemeriksaan untuk penapisan depresi. (B) Edukasi terkait tatalaksana depresi dan faktor-faktor risikonya pada pasien dan anggota keluarganya.
e-ISSN : 2715-2537

p-ISSN : 2715-2545

Data demografik menunjukkan bahwa sebagian besar subjek yang turut berpartisipasi dalam kegiatan pengabdian kepada masyarakat ini memiliki rentang usia $51-60$ tahun, berjenis kelamin laki-laki, dan memiliki tingkat pendidikan rendah (lama pendidikan formal $\leq 12$ tahun). Data karakteristik klinik menujukkan bahwa sebagian besar subjek mengalami stroke iskemik yang melibatkan hemisfer otak sisi kiri dan memiliki penyakit hipertensi. Subjek dengan faktor-faktor risiko seperti merokok, diabetes melitus, kegemukan, dan atrial fibrilasi dalam proporsi yang kecil. Subjek yang terdeteksi mengalami depresi dalam kegiatan ini ternyata cukup tinggi, yaitu sebesar $45 \%$. Hasil selengkapnya terkait data demografik dan klinik dan luaran klinis subjek dengan stroke iskemik dalam kegiatan ini dapat dilihat pada Tabel 1 .

Tabel 1. Karakteristik Demografik dan Klinik dan Luaran Klinis Subjek dengan Stroke Iskemik di RSUD Provinsi NTB

\begin{tabular}{lll}
\hline Kategori & Frekuensi (n=22) & \% \\
\hline Karakteristik demografik & & \\
Usia & 7 & 31,8 \\
$\quad 40-50$ tahun & 11 & 15,0 \\
$51-60$ tahun & 4 & 18,2 \\
$\quad 61-70$ tahun & 15 & \\
Jenis kelamin & 7 & 68,2 \\
$\quad$ Laki-laki & & 31,8 \\
$\quad$ Perempuan & 16 & 72,7 \\
Lama pendidikan formal & 6 & 27,3 \\
$\quad$-12 tahun & & \\
$\quad$ >12 tahun & 10 & 45,5 \\
Karakteristik klinik & 12 & 54,5 \\
Hemisfer yang terkena & 8 & 36,4 \\
$\quad$ Kanan & 21 & 95,5 \\
$\quad$ Kiri & 9 & 40,9 \\
Status merokok & 11 & 50,0 \\
Hipertensi & 6 & 27,3 \\
Diabetes melitus & 1 & 4,5 \\
Dislipidemia & & \\
Kegemukan (overweight) & 10 & 45,5 \\
Atrial fibrilasi & & \\
Luaran klinis & & \\
Depresi pasca stroke & &
\end{tabular}


Tingginya proporsi subjek dengan stroke iskemik yang masuk dalam kelompok usia produktif (berusia $\leq 60$ tahun) dan berjenis kelamin laki-laki yang ikut dalam kegiatan pengabdian kepada masyarakat ini menunjukkan adanya potensi tingginya beban sosio-ekonomi pasien dan keluarganya. Hal ini disebabkan karena kelompok subjek tersebut yang seharusnya masih aktif bekerja, saat ini berpotensi untuk mengalami penurunan atau hilangnya produktivitas kerja akibat penyakit stroke yang dialaminya. Kondisi depresi yang menjadi komorbid pada subjek dengan stroke iskemik tersebut akan meningkatkan risiko untuk terjadinya penurunan produktivitas kerja yang lebih berat, peningkatan kompleksitas pengobatan, penurunan efektivitas pengobatan yang diterima, dan terhambatnya proses penyembuhan subjek tersebut (Husaini et al., 2013; Paolucci et al., 2019). Jika kondisi depresi yang dialami oleh subjek tersebut berkembang menjadi lebih berat, subjek tersebut akan memiliki ketergantungan yang tinggi terhadap anggota keluarganya untuk melakukan aktivitas fungsional dan sosialnya sehari-hari. Hal ini nantinya akan menyebabkan waktu yang dimiliki oleh anggota keluarga menjadi lebih banyak dialokasikan untuk merawat subjek tersebut, sehingga produktivitas kerja mereka juga akan ikut menurun dan beban sosio-ekonomi keluarga akan menjadi semakin meningkat.

Besarnya potensi masalah yang ditimbulkan oleh depresi pada pasien stroke iskemik, seperti yang dideskripsikan diatas, sangat penting untuk dipahami oleh subjek dan/atau keluarganya. Dengan demikian, mereka juga perlu memahami bahwa deteksi dini depresi dan edukasi terkait penatalaksanaannya secara dini untuk memperbaiki luaran klinisnya, yaitu tercapainya perbaikan kapasitas fungsional sehari-hari subjek dengan stroke iskemik yang optimal, sangat penting untuk dilakukan. Dalam kegiatan ini, baik subjek dengan stroke iskemik maupun anggota keluarga yang mendampinginya menunjukkan antusiasme yang tinggi (Gambar 1). Anggota keluarga yang mengasuh subjek secara aktif bertanya mengenai tindakan apa saja yang harus ditempuh agar subjek yang mereka rawat tidak sampai mengalami depresi atau jika mengalami depresi, bisa segera mendapatkan penanganan yang tepat. Mereka mampu memahami dan menyadari bahwa penurunan kapasitas fungsional akibat depresi pada subjek dengan stroke iskemik yang mereka rawat akan juga menurunkan produktivitas kerja mereka dan meningkatkan beban sosio-ekonomi keluarga.

Seperti yang telah disampaikan sebelumnya, sebagian besar subjek memiliki tingkat pendidikan rendah (tabel 1). Mengingat kegiatan edukasi ini membutuhkan kemampuan mereka dalam memahami informasi dan instruksi yang diberikan, maka tingginya prorposi subjek dengan tingkat pendidikan yang rendah tersebut menjadi tantangan tersendiri untuk tercapainya tujuan dari kegiatan ini. Dalam hal ini, partisipasi aktif anggota keluarga yang mengasuhnya dalam menerima dan memahami informasi yang diberikan menjadi sangat penting (Towfighi et al., 2017; Shi et al., 2017). Informasi disampaikan relatif sederhana relatif sederhana dan mudah dipahami anggota keluarga yang mendampinginya. Hal ini bisa dilihat dengan partisipasi aktif mereka dalam bertanya atau mengonfirmasi apakah pemahaman mereka miliki terkait informasi yang diberikan dalam kegiatan edukasi ini sudah sesuai dengan yang diharapkan atau belum (Gambar 1).

Tabel 2 menunjukkan bahwa karakteristik demografik dan klinik yang dimiliki oleh subjek dengan stroke iskemik tidak berhubungan secara signifikan dengan kejadian depresi pasca stroke $(\mathrm{p}<0.05)$. Hasil ini berbeda dengan penelitian sebelumnya yang menyebutkan bahwa usia, jenis kelamin, dan tingkat pendidikan, hipertensi, keterlibatan hemisfer kiri merupakan faktor risiko utama untuk terjadinya depresi pada pasien stroke (Shi et al., 2017; Tennen et al., 2011). Namun demikian, terlepas dari hasil analisis secara statistik tersebut, keberadaan faktor-faktor risiko tersebut, serta karakteristik klinik lainnya, seperti merokok, diabetes melitus, dislipidemia, kegemukan (overweight), dan atrial fibrilasi bukan berarti tidak penting. Penatalaksanaan terhadap semua faktorfaktor risiko tersebut, selain faktor usia yang tidak dapat dimodifikasi, juga merupakan salah satu upaya penting dalam penatalaksanaan depresi. Edukasi terkait penatalaksanaan secara farmakologis dan non-farmakologis terhadap faktor-faktor risiko depresi pasca stroke yang teridentifikasi tersebut kepada subjek dan anggota keluarganya dalam kegiatan ini juga dilakukan dengan sesederhana mungkin agar dipahami dengan baik oleh mereka. Dalam kegiatan edukasi terkait hal ini, subjek dan anggota keluarga yang 
mendampinginya juga menunjukkan antusiasme yang tinggi, yang ditunjukkan dengan partisipasi aktif mereka dalam bertanya terkait penjelasan atas informasi yang disampaikan.

Tabel 2. Hubungan antara Karakteristik Demografik dan Klinik dan Luaran Klinis Pasien Stroke Iskemik di RSUD Provinsi NTB

\begin{tabular}{|c|c|c|c|}
\hline \multirow[t]{2}{*}{ Kategori } & \multicolumn{2}{|c|}{ Status depresi, n(\%) } & \multirow[t]{2}{*}{ Nilai $p$} \\
\hline & $\begin{array}{c}\text { Depresi } \\
(n=10)\end{array}$ & $\begin{array}{c}\text { Normal } \\
(n=12)\end{array}$ & \\
\hline \multicolumn{4}{|l|}{ Usia } \\
\hline $40-50$ tahun & $4(57,1)$ & $3(43,9)$ & 0.675 \\
\hline $51-60$ tahun & $4(36,4)$ & $7(63,6)$ & \\
\hline $61-70$ tahun & $2(50,0)$ & $2(50,0)$ & \\
\hline \multicolumn{4}{|l|}{ Jenis kelamin } \\
\hline Laki-laki & $7(46,7)$ & $8(53,3)$ & 0,867 \\
\hline Perempuan & $3(42,9)$ & $4(57,1)$ & \\
\hline \multicolumn{4}{|c|}{ Lama pendidikan formal } \\
\hline$\leq 12$ tahun & $9(56,3)$ & $7(43,7)$ & 0,097 \\
\hline$>12$ tahun & $1(16,7)$ & $5(83,3)$ & \\
\hline \multicolumn{4}{|l|}{ Hemisfer yang terkena } \\
\hline Kanan & $4(40,0)$ & $6(60,0)$ & 0,639 \\
\hline Kiri & $6(50,0)$ & $6(50,0)$ & \\
\hline \multicolumn{4}{|l|}{ Status merokok } \\
\hline $\mathrm{Ya}$ & $5(62,5)$ & $3(37,5)$ & 0,225 \\
\hline Tidak & $5(35,7)$ & $9(64,3)$ & \\
\hline \multicolumn{4}{|l|}{ Hipertensi } \\
\hline $\mathrm{Ya}$ & $9(42,9)$ & $12(57,1)$ & 0,262 \\
\hline Tidak & $1(100,0)$ & $0(0,0)$ & \\
\hline \multicolumn{4}{|l|}{ Diabetes melitus } \\
\hline $\mathrm{Ya}$ & $5(55,6)$ & $4(44,4)$ & 0,429 \\
\hline Tidak & $5(38,5)$ & $8(61,5)$ & \\
\hline \multicolumn{4}{|l|}{ Dislipidemia } \\
\hline $\mathrm{Ya}$ & $5(45,5)$ & $6(54,5)$ & 1,000 \\
\hline Tidak & $5(45,5)$ & $6(54,5)$ & \\
\hline \multicolumn{4}{|c|}{ Kegemukan (overweight) } \\
\hline $\mathrm{Ya}$ & $2(33,3)$ & $4(66,7)$ & 0,484 \\
\hline Tidak & $8(50,0)$ & $8(50,0)$ & \\
\hline \multicolumn{4}{|l|}{ Atrial fibrilasi } \\
\hline $\mathrm{Ya}$ & $0(0,0)$ & $1(100,0)$ & 0,350 \\
\hline Tidak & $10(47,6)$ & $11(52,4)$ & \\
\hline
\end{tabular}

Uji kai-kuadrat, signifikan jika nilai $\mathrm{p}<0,05$

Manfaat kegiatan pengabdian kepada masyarakat ini terhadap peningkatan derajat kesehatan subjek dengan stroke iskemik dapat dilihat cukup besar. Oleh karena itu, maka kegiatan ini diharapkan dapat terus dilanjutkan, tidak hanya di RSUD Provinsi NTB, namun juga di rumah sakit-rumah sakit lainnya di Provinsi NTB. Perlu dilakukan evaluasi secara berkala setiap 6 bulan untuk memastikan bahwa depresi pasca stroke dapat dicegah, kondisi depresi yang sudah dialami oleh subjek dengan stroke mengalami perbaikan yang bermakna atau sembuh, kapasitas fungsional subjek tercapai secara optimal, faktor-faktor risiko yang dapat dimoifikasi dapat terkontrol dengan baik, dan kendala-kendala yang dialami oleh subjek dan keluarga yang mengasuhnya dalam menerapkan rekomendasi yang diberikan dalam kegiatan pengabdian ini terkait penatalaksanaan depresi pasca stroke dapat segera dideteksi dan dipecahkan secara bersama-sama. Dengan evaluasi secara berkala tersebut, maka tujuan promotif dan preventif dari kegiatan pengabdian kepada masyarakat ini dapat tercapai. 
Harahap et al, Jurnal Pengabdian Masyarakat Sains Indonesia 2021, 3 (1): 219-225. DOI: https://doi.org/10.29303/jpmsi.v3i1.109

\section{Kesimpulan}

Dalam kegiatan pengabdian kepada masyarakat ini, frekuensi subjek dengan stroke iskemik dengan awitan 3 bulan pertama yang datang ke Poli Saraf RSUD Provinsi NTB dengan kondisi depresi cukup tinggi. Usia produktif, jenis kelamin laki-laki, tingkat pendidikan rendah, lokasi infark pada hemisfer kiri, dan hipertensi merupakan faktor-faktor risiko yang dapat diidentifikasi dengan proporsi tinggi, namun tidak memiliki hubungan yang signifikan dengan frekuensi kejadian depresi pasca stroke. Kegiatan edukasi terkait deteksi dini depresi pasca stroke dan edukasi terkait pentingnya penatalaksanaan depresi dan faktor-faktor risiko penyertanya pada pasien stroke iskemik sangat diperlukan, baik oleh subjek dengan stroke iskemik dan anggota keluarga yang merawatnya.

\section{Saran}

Perlu dilakukan evaluasi secara berkala untuk memastikan bahwa depresi pasca stroke dapat dicegah atau tertangani dengan baik.

\section{Ucapan Terima Kasih}

Penulis menyampaikan terima kasih kepada Lembaga Penelitian dan Pengabdian kepada Masyarakat (LPPM) Universitas Mataram dan pihak Rumah Sakit Umum Daerah (RSUD) Provinsi NTB yang turut memfasilitasi pelaksanaan kegiatan ini.

\section{Daftar Pustaka}

Ezema, C. I., Akusoba, P. C., Nweke, M. C., Uchewoke, C. U., Agono, J., Usoro, G. 2018. Influence of post-stroke depression on functional independence in activities of daily living. Ethopian Journal of Health Sciences, (1), 29, 841.

Harahap, S., Harahap, Z., dan Yusdiana, D. 2017. Correlation of the capacity of bodily functions and family support with the depression in post stroke patients. International Journal of Nursing, (2), 4, 106 $-113$.

Husaini, B. H., Levine, R., Sharp, L., Cain, V., Novotny, M., Hull, P., Orum,G., Samad, Z.,
e-ISSN : 2715-2537

p-ISSN : 2715-2545

Sampson, U., Muunis, M. 2013. Depression increases stroke rehabilitation cost: an analysis of 17,010 stroke patients in 2008 by race and gender. Stroke Research and Treatment, 2013, 846732.

Paolucci, S., Iosa, M., Coiro, P., Venturiero, V., Savo, A., De Angelis, D., Morone, G. 2019. Post-stroke depression increases disability more than $15 \%$ in ischemic stroke survivors: a case control study. Frontiers in Neurology, 10, 926.

Schottke, H., Gerke, L., Dusing, R., Mollmann, A. 2020. Post-stroke depression and functional impairments - a 3-year prospective study. Comprehensive Psychiatry, 99, 152171.

Shi, Y., Yang, D., Zeng, Y., Wu, W. 2017. Risk factors for post-stroke depression: a metaanalysis. Frontiers in Aging Neuroscience, 9, 218.

St-Hilaire, A., Hudon, C., Vallet, G. T., Bherer, L., Lussier, M., Gagnon, J., Simard, M., Gosselin, N., Escudier, F., Rouleau, I., Macoir, J. 2016. Normative data for phonemic and semantic verbal fluency test in the adult French-Quebec population and validation study in Alzheimer's disease and depression. The Clinical Neuropsychologist, (7), 30, 1126-1150.

Tennen, G., Herrmann, N., Black, S. E., Levy, K. S., Cappell, J., Li, A., Lanctot, K. L. 2011. Are vascular risk factors associated with post-stroke depressive symptoms? Journal of Geriatric Psychiatric and Neurology, (4), 24, 215-221.

Towfighi, A., Ovbiagele, B., El Husseini, N., Hackett, M. L., Jorge, R. E., Kissela, B. E., Mitchell, P. H., Skolarus, L. E., Whooley, M. A., Williams, L. S. 2017. Poststroke depression: a scientifc statement for healthcare professionals from the American Heart Association/American Stroke Association. Stroke, 48, e30-e43. 